\title{
DIVERSITY OF MICROBIAL SECONDARY METABOLITES
}

\author{
K. Kondrashevska, I. Kliuchka, T. Pirog, Yu. Penchuk \\ National University of Food Technologies
}

\begin{tabular}{|c|c|}
\hline Key words: & ABSTRACT \\
\hline $\begin{array}{l}\text { Microbial secondary } \\
\text { metabolites } \\
\text { Antibacterial } \\
\text { Antifungal } \\
\text { Antiviral activity } \\
\text { Cytotoxic effect }\end{array}$ & $\begin{array}{l}\text { Interest to microbial secondary metabolites (products of } \\
\text { microbial synthesis that are not necessary for the growth and } \\
\text { propagation of a biological agent) is due to their unique bio- } \\
\text { logical properties, which are found to be practical in various } \\
\text { industries: food, chemical, oil industry, environmental pro- } \\
\text { tection, agriculture, and also in the pharmaceutical industry }\end{array}$ \\
\hline $\begin{array}{l}\quad \text { Article history: } \\
\text { Received } 06.09 .2018 \\
\text { Received in revised form } \\
19.09 .2018 \\
\text { Accepted } 18.10 .2018\end{array}$ & $\begin{array}{l}\text { and medicine. Such metabolites include antibiotics, exopoly- } \\
\text { saccharides, surfactants, antiviral and cytotoxic agents, } \\
\text { enzyme inhibitors. The need to search for new products of } \\
\text { microbial synthesis is primarily due to the rapid spread of } \\
\text { antibiotic resistance of many pathogens of infectious diseases. }\end{array}$ \\
\hline $\begin{array}{l}\text { Corresponding author: } \\
\text { K. Kondrashevska } \\
\text { E-mail: } \\
\text { npnuht@ukr.net }\end{array}$ & $\begin{array}{l}\text { In addition, studies of low-toxic antitumor compounds, immu- } \\
\text { nosuppressors and enzyme inhibitors that can replace che- } \\
\text { mical analogues that exert an immunosuppressive, mutagenic } \\
\text { and teratogenic effect on healthy human cells are important. } \\
\text { In this paper, modern literature data on the synthesis of } \\
\text { microbial secondary metabolites by epiphytic, free-living } \\
\text { (including marine) bacteria (representatives of the Bacilla- } \\
\text { ceae and Paenibacillaceae families), actinobacteria of the } \\
\text { Streptomycetaceae and Micromonosporaceae families, fungi } \\
\text { of the Trichocomaceae family (genera Talaromyces, } \\
\text { Aspergillus, Penicillium) are given. Due to a wide range of } \\
\text { biological activity (antibacterial, antifungal, antiviral and cy- } \\
\text { totoxic) they can be used as alternative chemical compounds } \\
\text { in medicine, as well as in agriculture to control the quantity } \\
\text { of phytopathogenic microorganisms. }\end{array}$ \\
\hline
\end{tabular}

DOI: $10.24263 / 2225-2924-2018-24-5-8$

\section{РОЗМАÏТТЯ МІКРОБНИХ ВТОРИННИХ МЕТАБОЛІТІВ}

\author{
К.Р. Кондрашевська, І.В. Ключка, Т.П. Пирог, Ю.М. Пенчук \\ Національний університет харчових технологій
}

Інтерес до мікробних вторинних метаболітів (продуктів мікробного синтезу, які не є необхідними для росту і розмноження біологічного агента), зумовлений їхніми унікальними біологічними властивостями, що знаходять практичне використання у різних галузях промисловості: харчовій, хімічній, нафтодобувній, охороні довкілля, сільському господарстві, а також у фармацевтичній галузі та медицині. До таких метаболітів належать антибіотики, екзополісахариди, поверхнево-активні речовини, антивірусні та цичтотоксичні 
агенти, інгібітори ферментів. Необхідність пошуку нових продуктів мікробного синтезу зумовлена насамперед швидким поширенням антибіотикорезистентності багатьох збудників інфекиійних захворювань. Окрім изього, важливе значення мають дослідження низькотоксичних протипухлинних сполук, імуносупресорів та інгібіторів ферментів, які можуть замінити хімічні аналоги, що спричиняють імунодепресивну, мутагенну $і$ терогенну дію на здорові клітини людини.

У статті наведено сучасні літературні дані щзодо синтезу мікробних вторинних метаболітів епіфітними, вільноіснуючими (в тому числі й морськими) бактеріями (представниками родин Bacillaceae та Paenibacillaceae), актинобактеріями родини Streptomyсеtaceae ma Micromonosporaceae, грибами родини Trichocomaceae (роди Talaromyces, Aspergillus, Penicillium). Завдяки широкому спектру біологічної активності (антибактеріальна, антифунгальна, противірусна та цитотоксична) вони можуть бути використані як альтернативні хімічним сполукам у медицині, а також у сільському господарстві для контролю чисельності фітопатогенних мікроорганізмів.

Ключові слова: мікробні вторинні метаболіти, антибактеріальна, антифунгальна, антивірусна активність, цитотоксичний ефект.

Постановка проблеми. Вторинні метаболіти - сполуки, що синтезуються деякими видами мікроорганізмів, i, переважно утворюються після припинення росту у вигляді комплексу подібних сполук. Їхня здатність до синтезу часто втрачається в результаті мутацій або в процесі зберігання продуцентів. До вторинних метаболітів належить широкий спектр сполук: антибіотики, екзополісахариди, інгібітори ферментів, імуносупресори, полікетиди, терпени, терпеноїди, яким притаманний широкий спектр біологічної активності (табл. 1) [1].

Таблиця 1. Різні типи біологічної активності вторинних метаболітів [1]

\begin{tabular}{|c|c|c|}
\hline Активність & Характеристика & $\begin{array}{c}\text { Кількість досліджених } \\
\text { активностей }\end{array}$ \\
\hline \multirow{5}{*}{ Антимікробна } & Антибактеріальна: \\
& Грампозитивні бактерії & $11000-12000$ \\
& Грамнегативні бактерії & $5000-5500$ \\
& Мікобактерії & $800-1000$ \\
& Антифунгальна: & $3000-3600$ \\
& Дріжджі & $1600-1800$ \\
& Фітопатогенні гриби & $3800-4000$ \\
\hline \multirow{2}{*}{ Хіміотерапевтична } & Інші гриби & $5000-5500$ \\
& Протипухлинна (цитотоксична) & $1500-1600$ \\
\hline \multirow{2}{*}{ Фармакологічна } & Противірусна & $3000-3200$ \\
& Інгібітори ферментів & 800 \\
\hline
\end{tabular}

3 появою нових методів досліджень (в основному високоефективної рідинної хроматографії) з'явилася можливість швидкої ідентифікації синтезованих вторинних метаболітів. Необхідність пошуку нових продуктів мікроб- 
ного синтезу зумовлена насамперед поширенням антибіотикорезистентних штамів мікроорганізмів. Так, ще у 2014 р. тільки у Європі та США було зареєстровано 50 тисяч смертей, спричинених стійкими до антибіотиків збудниками інфекційних захворювань. За прогнозами вчених, до 2050 р. кількість смертей зросте до 10 мільйонів на рік, а витрати на введення нових антимікробних препаратів становитимуть 100 трильйонів доларів США у всьому світі $[2 ; 3]$.

Ще однією проблемою сьогодення залишається дослідження низькотоксичних протипухлинних препаратів, які можуть стати альтернативною заміною протибластомним засобам, що чинять імунодепресивну, мутагенну i терогенну дію на здорові клітини людини [4]. Окрім антимікробних та протипухлинних препаратів, актуальним $є$ пошук нових імуносупресорів i iнгібіторів ферментів, на основі яких вже створено такі медичні препарати, як такролімус - імуносупресор, синтезований представниками роду Streptomyces, ловастатин - інгібітор ферментів синтезу холестерину, утворюваний мікроміцетами роду Aspergillus [5; 6].

У зв'язку з викладеним вище мета цього огляду - узагальнити сучасні літературні дані щодо здатності різних мікроорганізмів синтезувати практично цінні біологічно-активні вторинні метаболіти.

Викладення основних результатів дослідження. Розглянемо вторинні метаболіти бактерій (у тому числі й актинобактерій) та грибів, що можуть мати потенційне практичне використання у багатьох галузях промисловості та медицини.

Вторинні метаболіти бактерій родин Васіllaceae ma Paenibacillaceae. У табл. 2 наведено дані щодо синтезу вторинних метаболів вільно існуючими, епіфітними та морськими бактеріями родини Bacillaceae та Paenibacillaceae. Представники цих родин здатні до синтезу антимікробних сполук (поверхнево-активні речовини [7], в тому числі й ліпопептиди [8], антимікробні пептиди [9-12]), а також екзополісахариди [13; 14] та інші речовини [15]. Так, антимікробні пептиди дикетопіранозин та ентіанін, синтезовані Bacillus sp N та Bacillus subtilis subsp. spizizenii DSM 15029 ${ }^{\mathrm{T}}$, у концентрації 4-64 мкг/мЛ проявляють антифунгальну дію щодо збудників хвороб людей Aspergillus flavus MTCC 183, Candida albicans MTCC 277, а такожа метицилін- і ванкоміцинрезистентних Staphylococcus aureus ATCC 43300, Enterococcus faecalis ATCC 51299, Micrococcus luteus ATCC 9341 [9; 11]. Окрім антифунгальної дії на збудників хвороб людини, дикетопіранозин і протеїн Е2 Bacillus subtilis EDR4 діють на фітопатогенні гриби. Так, за наявності 0,52 мкг/мл протеїну E2 зони затримки росту становили (мм): Fusarium graminearum - 125, Macrophoma kuwatsukai - 185, Rhizoctonia cerealis - 125, Fusarium oxysporum f. sp. vasinfectum - 145, Botrytis cinerea - 155), Gaeumannomyces graminis var. tritici - 225 [10].

Антифунгальну дію на фітопатогенні гриби (Gaeumannomyces graminis, Rhzioctonia cerealis, Helminthosporium sativum, Fusarium graminearum) проявляють і пептиди, синтезовані Halobacillus litoralis YS3106, однак у дещо вищій (200-800 мкг/мл) концентрації [12].

Метаболіти Bacillus licheniformis SAB1 у концентрації 50 мкг/мл проявляють антимікробну активність: індол інгібує ріст Staphylococcus aureus, Sal- 
monella typhi та Candida albicans (зона затримки росту 7-10 мм), а 3-фенілпропіонова кислота спричиняє антифунгальну дію на Rhodotorula sp., Candida albicans, Aspergillus niger (зони затримки росту 4-10 мм) [15].

Окрім антимікробної та антифунгальної активності, метаболіти цих бактерій характеризуються антивірусною активністю. Так, наприклад, Geobacillus thermodenitrificans B3-72 та Bacillus licheniformis B3-15 синтезують екзополісахариди EPS-1 та EPS-2, яким у концентрації 300 мкг/мл притаманна антивірусна дія на вірус герпесу другого типу HSV-2 [13].

Екзополісахарид леван, синтезований Paenibacillus polymyxa EJS-3, та його ацетильовані, фосфорильовані та бензилові похідні проявляють цитотоксичну активність щодо клітини раку шлунку людини лінії BGC-823 у концентрації 400 мкг/мл [14].

Біологічно активні речовини актинобактерій родин Streptomycetaceae ma Micromonosporaceae. Велику кількість різноманітних вторинних метаболітів утворюють і актинобактерії родин Streptomycetaceae та Micromonosporaceae (табл. 3). 3 кінця 40-60-х років XX ст. (золотий вік антибіотиків) було виділено i введено в клінічну практику значну кількість антибіотиків, синтезованих представниками роду Streptomyces [16]. Крім антибіотиків [17], ці актинобактерії здатні синтезувати ряд інших вторинних метаболітів: антибіотикоподібні сполуки (полікетиди [18; 19], С-глікозильовані похідні бенз[ $]$ антрахінону [20], бенз[ $\alpha]$ антрахіноновий антибіотик [21]), антимікробні пептиди [22; 23], інгібітори ферментів та інші речовини: кислоти, похідні фенолу та альдегіди [24 -27].

Зазначимо, що найбільшу кількість актинобактерій роду Streptomyces було виділено з рослин. Наприклад, ендофітний штам Streptomyces sp. neau-D50, виділений з ризосфери сої, синтезує 3-ацетонілід-7-преніліндолін-2-он та 7ізопреніліндол-3-карбоксильна кислота, які за концентрацій 3,3 та 5,1 мкг/мл, відповідно, інгібують ракові клітини аденокарциноми легенів людини А-549, а також разом 3 іншими метаболітами (3-ціанометил-6-преніліндолом та 6ізопреніліндол-3-карбоксильною кислотою) проявляють антифунгальну активність щодо Colletotrichum orbiculare (30,55-50,22 мкг/мл), Phytophthora capsici (47,45-90,61 мкг/мл), Corynespora cassiicola (56,71-79,67 мкг/мл), Fusarium oxysporum (51,56-81,43 мкг/мл) [25]. Інший ендофітний штам, Streptomyces sp. YIM 67086 утворює похідне бензаміду, 2-аміно-3,4-дигідрокси-5-матоксибензамід, який за концентрації 68,6 мкг/мл проявляє антиоксидантну активність [26]. Окрім цього продуцента, антиоксидантною активністю $(4,61-$ 57,12 мкг/мл) за радикалом DPPH (1,1-дифеніл-2-пікрилгідразил) характеризуються метаболіти Streptomyces sp. YIM 666017 [24].

Таблиия 2. Біологічно-активні метаболіти бактерій родин Bacillaceae та Paenibacillaceae

\begin{tabular}{|c|c|c|c|c|}
\hline Бактерії & Метаболіти & $\begin{array}{c}\text { Біологічна активність } \\
\text { метаболітів та їх ефективна } \\
\text { концентрація (мкг/мл) або } \\
\text { зона затримки росту (мм) }\end{array}$ & $\begin{array}{c}\text { Сфера } \\
\text { потенційного } \\
\text { застосування }\end{array}$ & $\begin{array}{c}\text { Літе- } \\
\text { ратура }\end{array}$ \\
\hline 1 & 2 & 3 & 4 & 5 \\
\hline \multicolumn{4}{|c|}{ Вільноіснуючі } \\
\hline
\end{tabular}




\begin{tabular}{|c|c|c|c|c|}
\hline \multicolumn{5}{|c|}{ Продовження табл. 2} \\
\hline 1 & 2 & 3 & 4 & 5 \\
\hline \begin{tabular}{|} 
Bacillus \\
amyloliquefaciens \\
PPCB004
\end{tabular} & $\begin{array}{l}\text { Ліпопептиди: } \\
\text { ітурин А, } \\
\text { феніцин, } \\
\text { сурфактин А }\end{array}$ & \begin{tabular}{|c|} 
Антифунгальна \\
(фітопатогени): Alternaria citri \\
(3,1 мкг/мл), \\
Botryosphaeria sp. \\
(1,0 мкг/мл), Colletotrichum \\
gloeosporioides $(3,1$ мкг/мл), \\
Fusicoccum aromaticum \\
(2,1 мкг/ мл), Lasiodiplodia \\
theobromae $(1,0$ мкг/мл), \\
Penicillium crustosum \\
(1,0 мкг/мл), \\
Phomopsis persea $(1,5$ мкг/мл)
\end{tabular} & $\begin{array}{c}\text { Сільське } \\
\text { господарство }\end{array}$ & {$[8]$} \\
\hline Bacillus sp. N & \begin{tabular}{|} 
Дикетопіперазин \\
и: cyclo-(L-Pro-L- \\
Leu), cyclo-(D- \\
Pro-L-Leu) та \\
cyclo-(D-Pro-L- \\
Tyr)
\end{tabular} & 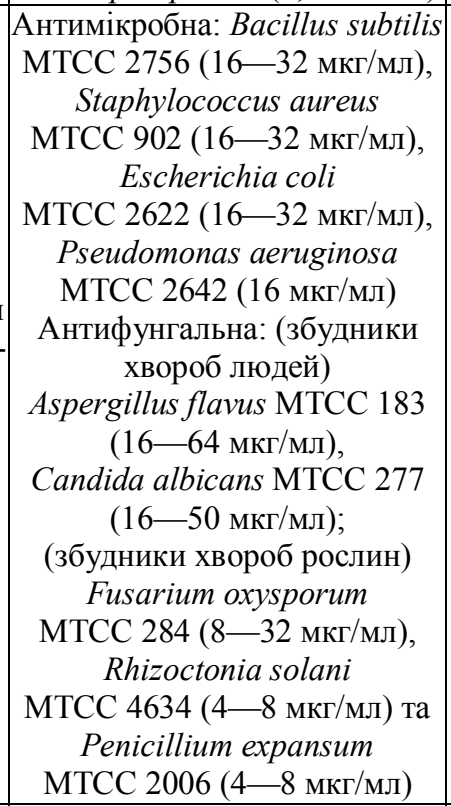 & \begin{tabular}{|c|} 
\\
Медицина \\
Фармацев- \\
тична \\
промисловість \\
Сільське \\
господарство \\
\\
\end{tabular} & [9] \\
\hline $\begin{array}{l}\text { Bacillus subtilis } \\
\text { subsp. spizizenii } \\
\text { DSM } 15029^{\mathrm{T}}\end{array}$ & Пептид: ентіанін & \begin{tabular}{|c|} 
Антибактеріальна: метицилін- \\
резистентний Staphylococcus \\
aureus ATCC 43300 \\
(8 мкг/мл), ванкоміцин- \\
резистентний Enterococcus \\
faecalis ATCC 51299 (8- \\
16 мкг/мл), Micrococcus luteus \\
АТСС 9341 (4-8 мкг/мл)
\end{tabular} & \begin{tabular}{|c|} 
Медицина \\
Фармацев- \\
тична \\
промисловість \\
\end{tabular} & {$[11]$} \\
\hline $\begin{array}{c}\text { Paenibacillus } \\
\text { macerans } \\
\text { TKU029 }\end{array}$ & $\begin{array}{c}\text { Поверхнево- } \\
\text { активна } \\
\text { речовина } \\
\text { Екзополісахарид }\end{array}$ & \begin{tabular}{|c|} 
Антибактеріальна: Escherichia \\
coli ВCRC13086 (2 мг/мл), \\
Staphylococcus aureus \\
ВСRC10780 (1,5 мг/мл) \\
Антифунгальна: Fusarium \\
oxysporum BCRC32121 \\
(4 мг/мл), Aspergillus fumigatus \\
ВСRC30099 (7,5 мг/мл)
\end{tabular} & \begin{tabular}{|c|} 
Медицина \\
Фармацев- \\
тична \\
промисловість \\
Косметологія \\
\end{tabular} & {$[7]$} \\
\hline
\end{tabular}




\begin{tabular}{|c|c|c|c|c|}
\hline \multicolumn{5}{|c|}{ Закінчення табл. 2} \\
\hline 1 & 2 & 3 & 4 & 5 \\
\hline \multicolumn{5}{|c|}{ Ендофітні } \\
\hline $\begin{array}{l}\text { Bacillus subtilis } \\
\text { EDR4 }\end{array}$ & Протеїн: Е2 & \begin{tabular}{|c|} 
Антифунгальна: \\
(фітопатогени) (0,52 мкг/мл) \\
Fusarium graminearum \\
(125 мм), Macrophoma \\
kuwatsukai (185 мм), \\
Rhizoctonia cerealis $(125 \mathrm{mм})$, \\
Fusarium oxysporum f. sp. \\
vasinfectum $(145 \mathrm{~mm})$, Botrytis \\
cinerea $(155 \mathrm{mм})$, \\
Gaeumannomyces graminis var. \\
tritici $(225 \mathrm{mм})$
\end{tabular} & $\mid$\begin{tabular}{|c|} 
Сільськогос- \\
подарська \\
промисловість \\
\end{tabular} & {$[10]$} \\
\hline $\begin{array}{c}\text { Paenibacillus } \\
\text { polymyxa EJS-3 }\end{array}$ & $\begin{array}{c}\text { Екзополісаха- } \\
\text { риди: леван та } \\
\text { його похідні } \\
\text { (ацетильований } \\
\text { леван (АЛ), } \\
\text { фосфорильовани } \\
\text { й леван (ФЛ), } \\
\text { бензиловий } \\
\text { леван (БЛ) }\end{array}$ & $\begin{array}{c}\text { Цитотоксична: клітини раку } \\
\text { шлунка людини лінії BGC-823 } \\
(55,37-95,50 \%-400 \text { мкг/мл) }\end{array}$ & Медицина & {$[14]$} \\
\hline \multicolumn{5}{|c|}{ Морського походження } \\
\hline $\begin{array}{c}\text { Halobacillus } \\
\text { litoralis YS3106 }\end{array}$ & $\begin{array}{c}\text { Циклічний } \\
\text { гексапептид: } \\
\text { халоліторалін А } \\
\text { Циклічні } \\
\text { тетрапептиди: } \\
\text { халоліторалін В- } \\
\text { C } \\
\end{array}$ & \begin{tabular}{|c|} 
Антифунгальна: Candida \\
albicans $(20-30$ мкг/мл), \\
Tricophyton rubrum (25- \\
40 мкг/мл), (патогени рослин) \\
Gaeumannomyces graminis \\
(300-400 мкг/мл), Rhzioctonia \\
cerealis $(200-350$ мкг/мл), \\
Helminthosporium sativum \\
(300-400 мкг/мл), Fusarium \\
graminearum $(350-800$ мкг/мл)
\end{tabular} & \begin{tabular}{|c|} 
Медицина \\
Фармацев- \\
тична \\
промисловість \\
Сільськогос- \\
подарська \\
промисловість \\
\end{tabular} & {$[12]$} \\
\hline $\begin{array}{l}\text { Bacillus } \\
\text { licheniformis } \\
\text { SAB1 }\end{array}$ & \begin{tabular}{|c} 
Гетероциклічна \\
сполука: індол \\
Карбонова \\
кислота: 3- \\
фенілпропіонова \\
кислота \\
Димер фенілпро- \\
піонової \\
кислоти: 4,4'- \\
оксибіс (3- \\
фенілпропіонова \\
кислота)
\end{tabular} & \begin{tabular}{|c|} 
Антибактеріальна: \\
Pseudomonas aeruginosa (4- \\
6 мм), Staphylococcus aureus \\
(4-10 мм), Salmonella typhi \\
(4-10 мм), Vibrio cholerae \\
(4-6 мм), Streptococcus \\
pyogenes (1-6 мм), \\
Acinetobacter sp. (1-6 мм) \\
Антифунгальна: Aspergillus \\
fumigatus (7-10 мм), \\
Rhodotorula sp. $(4-10 \mathrm{мм})$, \\
Candida albicans $(4-10 \mathrm{мм})$, \\
Aspergillus niger (1-6 мм)
\end{tabular} & \begin{tabular}{|c} 
Медицина \\
Фармацев- \\
тична \\
промисловість
\end{tabular} & {$[15]$} \\
\hline \begin{tabular}{|c|} 
Geobacillus \\
thermodenitrifican \\
s $\mathrm{B} 3-72$
\end{tabular} & $\begin{array}{c}\text { Екзополісахарид: } \\
\text { EPS-2 }\end{array}$ & \multirow{2}{*}{$\begin{array}{c}\text { Антивірсна: HSV-2 в } \\
\text { мононуклеарних клітинах } \\
\text { периферичної крові людини } \\
\text { (РВМС) (300 мкг/мл) }\end{array}$} & \multirow[t]{2}{*}{ Медицина } & \multirow[t]{2}{*}[13]{} \\
\hline $\begin{array}{l}\text { Bacillus licheni- } \\
\text { formis } \mathrm{B} 3-15\end{array}$ & $\begin{array}{c}\text { Екзополісахарид: } \\
\text { EPS-1 }\end{array}$ & & & \\
\hline
\end{tabular}


Таблиця 3. Біологічно-активні метаболіти актинобактерій родин Streptomycetaceae Ta Micromonosporaceae

\begin{tabular}{|c|c|c|c|c|}
\hline Продуценти & Метаболіти & $\begin{array}{c}\text { Біологічна активність } \\
\text { мікробних метаболітів та їх } \\
\text { ефективна концентрація } \\
\text { (мкг/мл) або зона затримки } \\
\text { росту (мм) } \\
\end{array}$ & $\begin{array}{c}\text { Сфера } \\
\text { потенційного } \\
\text { застосування }\end{array}$ & $\begin{array}{l}\text { Літе- } \\
\text { ратура }\end{array}$ \\
\hline 1 & 2 & 3 & 4 & 5 \\
\hline \multicolumn{5}{|c|}{ Родина Streptomycetaceae } \\
\hline \multicolumn{5}{|c|}{ Вільноіснуючі } \\
\hline $\begin{array}{c}\text { Streptomyces sp. } \\
\text { HG29 }\end{array}$ & $\begin{array}{l}\text { Антибіотики: } \\
\text { олігоміцин Е, } \\
\text { олігоміцин А }\end{array}$ & 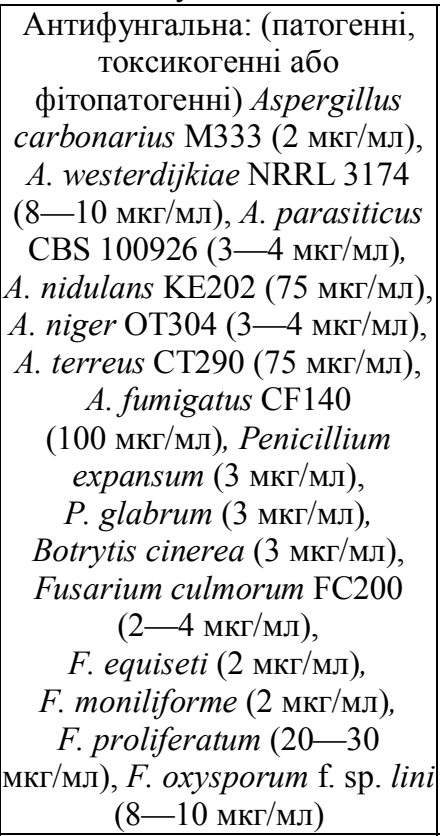 & \begin{tabular}{|c|} 
\\
\\
Медицина \\
Фармацев- \\
тична \\
промисловість \\
Сільськогос- \\
подарська \\
промисловість \\
\\
\end{tabular} & {$[1]$} \\
\hline $\begin{array}{c}\text { Streptomyces } \\
\text { coelicolor M145 }\end{array}$ & $\begin{array}{c}\text { Терпеноїди: } \\
\text { альбафлавенон } \\
\text { Полікетиди: } \\
\text { герміцидин А, } \\
\text { халкон }\end{array}$ & \begin{tabular}{|} 
Фунгістатична: Streptomyces \\
coelicolor $(4-8$ мкг/мл) \\
Антибактеріальна: Bacillus \\
subtilis ( 8 мкг/мл), \\
Arthrobacter crystallopoietes, \\
Mycobacterium smegmatis \\
\end{tabular} & \begin{tabular}{|c} 
Медицина \\
Фармацев- \\
тична \\
промисловість
\end{tabular} & {$[18]$} \\
\hline \multicolumn{5}{|c|}{ Ендофітні } \\
\hline $\begin{array}{l}\text { Streptomyces } \\
\quad \text { SUK } 25\end{array}$ & $\begin{array}{l}\text { Дикетопіперазин } \\
\text { и: сусlo-(L-Val- } \\
\text { L-Pro), cyclo- } \\
\text { (L-Leu-L-Pro), } \\
\text { cyclo-(L-Phe-L- } \\
\text { Pro), cyclo-(L- } \\
\text { Val-L-Phe) } \\
\text { Похідна } \\
\text { ацетаміду: N-(7- } \\
\text { hydroxy-6- } \\
\text { methyl-octyl)- } \\
\text { acetamide }\end{array}$ & \begin{tabular}{|} 
Антимікробна: метицилін- \\
резистентний Staphylococcus \\
aureus ATCC 43300 (15 мм), \\
Enterococcus raffinosus ATCC \\
49464 (13-14 мм) \\
Цитотоксична: клітини \\
людської гепатоми НераRG \\
(103,2-110,1 мкг/мл)
\end{tabular} & \begin{tabular}{|c|} 
Медицина \\
Фармацев- \\
тична \\
промисловість
\end{tabular} & {$[22]$} \\
\hline
\end{tabular}




\begin{tabular}{|c|c|c|c|c|}
\hline & & & \multicolumn{2}{|c|}{ Продовження табл. 3} \\
\hline 1 & 2 & \begin{tabular}{|c|}
3 \\
\end{tabular} & 4 & 5 \\
\hline $\begin{array}{c}\text { Streptomyces } \\
\text { sundarbansensis } \\
\text { MS } 1 / 7^{\mathrm{T}}\end{array}$ & $\begin{array}{c}\text { Полікетид: } \\
\text { фаеохроміцин C }\end{array}$ & $\begin{array}{c}\text { Антимікробна: Escherichia coli } \\
\text { АТСС } 25922 \text { (16 мкг/мл), } \\
\text { метицилін-резистентний } \\
\text { Staphylococcus aureus АТCC } \\
43300 \text { (2 мкг/мл) }\end{array}$ & \begin{tabular}{|c|} 
Медицина \\
Фармацев- \\
тична \\
промисловість
\end{tabular} & [19] \\
\hline $\begin{array}{l}\text { Streptomyces sp. } \\
\text { YIM66017 }\end{array}$ & 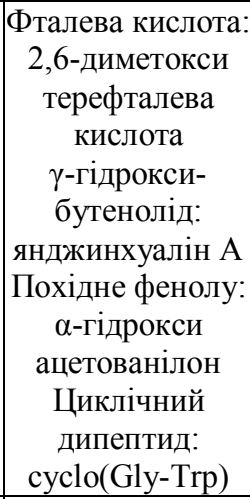 & $\begin{array}{c}\text { Антиоксидантна: за } \\
\text { радикалом DPPH } \\
\text { (1,1-дифеніл-2- } \\
\text { пікрилгідразил) }(4,61-57,12 \\
\text { мкг/мл) } \\
\end{array}$ & $\begin{array}{c}\text { Харчова } \\
\text { промисловість }\end{array}$ & {$[24]$} \\
\hline $\begin{array}{c}\text { Streptomyces sp. } \\
\text { neau-D50 }\end{array}$ & $\begin{array}{c}\text { Пренілований } \\
\text { індол: 3-ацето- } \\
\text { нілідин-7-прені- } \\
\text { ліндолін-2-1 } \\
\text { Ізопреноїди: } \\
\text { 7-ізопреніліндол- } \\
\text { 3-карбоксильна } \\
\text { кислота, } \\
\text { 3-ціанометил-6- } \\
\text { преніліндол, } \\
\text { 6-ізопреніліндол- } \\
\text { 3-карбоксильна } \\
\text { кислота }\end{array}$ & $\begin{array}{c}\text { Цитотоксична: } \\
\text { аденокарцинома легенів } \\
\text { людини А-549 (3,3-5,1 } \\
\text { мкг/мл) } \\
\text { Антифунгальна: } \\
\text { (фітопатогени) Colletotrichum } \\
\text { orbiculare (30,55- } \\
\text { 50,22 мкг/мл), Phytophthora } \\
\text { capsici (47,45-90,61 мкг/мл), } \\
\text { Corynespora cassiicola } \\
\text { (56,71-79,67 мкг/мл), } \\
\text { Fusarium oxysporum } \\
\text { (51,56-81,43 мкг/мл) }\end{array}$ & $\begin{array}{c}\text { Медицина } \\
\text { Сільське } \\
\text { господарство }\end{array}$ & {$[25]$} \\
\hline $\begin{array}{l}\text { Streptomyces sp. } \\
\text { YIM } 67086\end{array}$ & $\begin{array}{l}\text { Бензамід: 2-аміно- } \\
\text { 3,4- дигідрокси-5- } \\
\text { матоксибензамід } \\
\text { Дигідроксибензо } \\
\text { йна кислота: 4- } \\
\text { гідрокси-3-мето- } \\
\text { ксибензойна } \\
\text { кислота } \\
\text { Похідне фенолу: } \\
\text { фенілоцтова } \\
\text { кислота } \\
\text { Амід: N-ацетил- } \\
\text { тирамін } \\
\text { Стереоізомер } \\
\text { дициклічних кар- } \\
\text { бонових кислот: } \\
\text { р-гідрокситрук- } \\
\text { синова кислота }\end{array}$ & $\begin{array}{c}\text { Антимікробна: Escherichia coli } \\
\text { (64 мкг/мл), Candida albicans } \\
\text { (32-64 мкг/мл) } \\
\text { Антиоксидантна: за } \\
\text { радикалом DРРН (1,1- } \\
\text { дифеніл-2-пікрилгідразил) } \\
\text { (68,6 мкг/мл) } \\
\end{array}$ & $\mid \begin{array}{c}\text { Медицина } \\
\text { Фармацев- } \\
\text { тична } \\
\text { промисловість } \\
\text { Харчова } \\
\text { промисловість }\end{array}$ & {$[26]$} \\
\hline
\end{tabular}




\begin{tabular}{|c|c|c|c|c|}
\hline \multicolumn{5}{|c|}{ Закінчення табл. 3} \\
\hline 1 & 2 & 3 & 4 & 5 \\
\hline $\begin{array}{c}\text { Jishengella } \\
\text { endophytica } \\
161111\end{array}$ & $\begin{array}{c}\beta \text {-Карбоніли: } \\
\text { перлолірин, 1- } \\
\text { гідрокси- } \beta- \\
\text { карболін } \\
\text { Похідне } \\
\text { піразину: } \\
\text { люміхром } \\
\text { Альдегід: } 1 H \text { - } \\
\text { індол-3- } \\
\text { карбоксальдегід } \\
\end{array}$ & $\begin{array}{l}\text { Антивірусна: грип типу А } \\
\text { (H1N1) }(25,0-45,9 \text { мкг/мл) }\end{array}$ & Медицина & {$[27]$} \\
\hline \multicolumn{5}{|c|}{ Морського походження } \\
\hline $\begin{array}{c}\text { Streptomycetes sp. } \\
\text { BCC } 45596\end{array}$ & 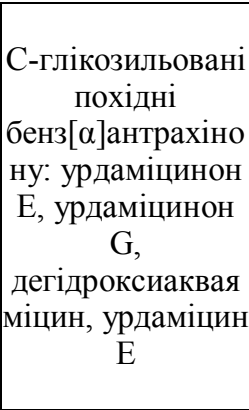 & $\begin{array}{c}\text { Антималярійна: Plasmodium } \\
\text { falciparum }(0,0534-2,93 \\
\text { мкг/мл) } \\
\text { Антитуберкульозна: } \\
\text { мycobacterium tuberculosis } \\
\text { (3,13-12,50 мкг/мл) } \\
\text { Цитотоксична: ракові клітини } \\
\text { ліній КВ }(0,179-6,96 \text { мкг/мл), } \\
\text { МСF-7 (0,196-3,41 мкг/мл), } \\
\text { NCI-Н187 (0,092-3,97 } \\
\text { мкг/мл) }\end{array}$ & Медицина & {$[20]$} \\
\hline $\begin{array}{l}\text { Streptomyces sp. } \\
\text { CNS-575 }\end{array}$ & \begin{tabular}{|} 
Депсипептиди: \\
фіджиміцини А- \\
С \\
Циклічний \\
пептид: етаміцин \\
А
\end{tabular} & $\begin{array}{l}\text { Антимікробна: метицилін- } \\
\text { резистентний Staphylococcus } \\
\text { aureus (4-16 мкг/мл) }\end{array}$ & $\begin{array}{c}\text { Медицина } \\
\text { Фармацев- } \\
\text { тична } \\
\text { промисловість }\end{array}$ & {$[23]$} \\
\hline $\begin{array}{c}\text { Micromonospora } \\
\text { rosaria SCSIO } \\
\text { N160 }\end{array}$ & 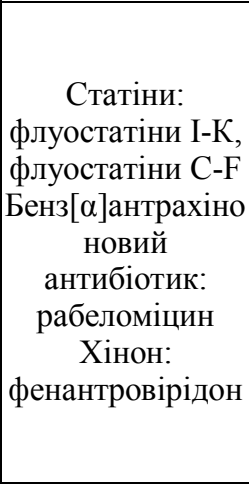 & \begin{tabular}{|c} 
Антибактеріальна: \\
Staphylococcus aureus АТСС \\
29213 (0,25-32 мкг/мл), \\
Escherichia coli АТСС 25922 \\
(16-32 мкг/мл), Bacillus \\
thuringiensis SCSIO ВT01 \\
(4-8 мкг/мл), Bacillus subtilis \\
SCSIO ВS01 (16-64 мкг/мл) \\
Цитотоксична: ракові клітини \\
людини SF-268 \\
(0,09-5,54 мкM), МСF-7 \\
(0,17-4,28 мкМ), NCI-Н460 \\
$(2,18-9,91$ мкг/мл)
\end{tabular} & $\begin{array}{c}\text { Медицина } \\
\text { Фармацев- } \\
\text { тична } \\
\text { промисловість } \\
\end{array}$ & {$[21]$} \\
\hline
\end{tabular}

Полікетиди Герміцидин А та Балкон, утворені Streptomyces coelicolor M145 [18] та Фаеохроміцин Streptomyces sundarbansensis MS1/7 ${ }^{\mathrm{T}}$ [19] у досить низьких концентраціях спричиняють антимікробний ефект щодо широкого кола мікроорганізмів: Bacillus subtilis (8 мкг/мл), Escherichia coli ATCC 25922 (16 мкг/мл), метицилін-резистентний Staphylococcus aureus ATCC 43300 (2 мкг/мл). Схожі властивості проявляють диспептиди фіджиміцин А-Е та циклічний пептид етаміцин A, синтезовані Streptomyces sp. CNS-575, які у концентрації 4 16 мкг/мл інгібують ріст метицилін-резистентного Staphylococcus aureus. 
Окрім антимікробної активності, метаболіти актинобактерій характеризуються і цитотосичною дією.

Так, Micromonospora rosaria SCSIO N160, виділений з Південного Китайського моря, синтезує рабеломіцин та фенантровіридон, що за концентрації 1,0 та 0,25 мкг/мл, відповідно, проявляють антибактеріальну дію на Staphylococcus aureus ATCC 29213 [21]. Окрім цього, фенантровірідон за концентрацій 0,09 та 0,17 мкМ додатково інгібує ракові клітини SF-268 та MCF-7 відповідно [21]. Цитотоксична активність щодо клітини людської гепатоми HepaRG (103,2-110,1 мкг/мл) та аденокарцинома легенів людини A-549 (3,3-5,1 мкг/мл) притаманна метаболітам (дикетопіперазин, похідна ацетаміду та преніловий індол, ізопреноїди) Streptomyces SUK 25 [22] та Streptomyces sp. neau-D50 [25] відповідно.

Вторинні метаболіти, синтезовані грибами. Окрім бактерій та актинобактерій, широкий спектр вторинних метаболітів синтезують гриби. Найвідомішими 3 них $є \beta$-лактамні антибіотики, до яких належать пеніциліни та цефалоспорини [28]. Нові, практично цінні продукти грибного походження наведено у табл. 4.

Найбільшу кількість практично цінних сполук синтезують представники класу Eurotiomycetes, родини Trichocomaceae, родів Talaromyces, Aspergillus, Penicillium.

Таблиия 4. Біологічно-активні метаболіти грибів

\begin{tabular}{|c|c|c|c|c|}
\hline Гриби & Метаболіти & $\begin{array}{c}\text { Біологічна активність } \\
\text { мікробних метаболітів та їх } \\
\text { ефективна концентрація } \\
\text { (мкг/мл) або зона затримки } \\
\text { росту (мм) }\end{array}$ & $\begin{array}{c}\text { Сфера } \\
\text { потенційного } \\
\text { застосування }\end{array}$ & $\begin{array}{c}\text { Літе- } \\
\text { ратура }\end{array}$ \\
\hline 1 & 2 & 3 & 4 & 5 \\
\hline \multicolumn{5}{|c|}{ Вільноіснуючі } \\
\hline $\begin{array}{l}\text { Talaromyces } \\
\text { thermophilus } \\
\text { YM1-3 }\end{array}$ & $\begin{array}{c}\text { Алкалоїди: } \\
\text { талатермофілінс } \\
\text { А та В }\end{array}$ & $\begin{array}{c}\text { Нематоцидна токсичність: } \\
\text { Panagrellus redivivus }(0,5-1,0 \\
\text { мкг/мл) }\end{array}$ & Медицина & [29] \\
\hline $\begin{array}{c}\text { T. pinophilus } \\
\text { AF-02 }\end{array}$ & $\begin{array}{c}\text { Естери: } \\
\text { талароміколіди } \\
\text { А-С } \\
\text { Жирна кислота: } \\
\text { 2-гідроксирадік- } \\
\text { лонова кислота }\end{array}$ & \begin{tabular}{|c|} 
Антибактеріальна: Bacillus sub- \\
tilis $(3,13-100$ мкг/мл), B. me- \\
gaterium (12,5-100 мкг/мл), \\
Escherichia coli $(12,5-100$ \\
мкг/мл), Clostridium perfringens \\
(12,5-100 мкг/мл), Micrococcus \\
tetragenus (12,5-100 мкг/мл)
\end{tabular} & \begin{tabular}{|c|} 
Медицина \\
Фармацев- \\
тична \\
промисловість \\
\end{tabular} & {$[30]$} \\
\hline $\begin{array}{c}\text { Aspergillus } \\
\text { flavipes MM2 }\end{array}$ & $\begin{array}{c}\text { Стерол: } \\
\text { ергостерол } \\
\text { Бутиролактони: } \\
\text { бутиролактон I, } \\
\text { аспульвінон H, } \\
\text { бутиролактон-V, } \\
\text { 4,4'- дигідрокси- } \\
\text { пульвінон } \\
\text { Аналог циклопен- } \\
\text { тенону: терріен } \\
\end{array}$ & $\mid \begin{array}{c}\text { Антибактеріальна: (40 мкг/мл) } \\
\text { Bacillus subtilis (11 мм), Staphy- } \\
\text { lococcus aureus (11-19 мм) } \\
\text { Цитотоксична: (10 мкг/мл) } \\
\text { солоні креветки (100\%) } \\
\end{array}$ & \begin{tabular}{|c|} 
Медицина \\
Фармацев- \\
тична \\
промисловість \\
Сільське \\
господарство
\end{tabular} & [39] \\
\hline
\end{tabular}




\begin{tabular}{|c|c|c|c|c|}
\hline \multicolumn{5}{|c|}{ Продовження табл. 4} \\
\hline 1 & 2 & 3 & 4 & 5 \\
\hline $\begin{array}{c}\text { Aspergillus } \\
\text { aculeatus KKU- } \\
\text { CT2 }\end{array}$ & $\begin{array}{l}\text { Стероїди: } \\
\text { перекис } \\
\text { ергостеролу, } \\
\text { ергостерол } \\
\text { Кислоти: } \\
\text { секалонова } \\
\text { кислота D та F } \\
\text { Терпеноїд: } \\
\text { варієколін } \\
\text { Естер: } \\
\text { варієколактон }\end{array}$ & $\begin{array}{c}\text { Цитотоксична: КВ (людська } \\
\text { епідермічна карцинома в роті) } \\
\text { (0,289-33,71 мкг/мл), NCI- } \\
\text { Н187 (рак легенів) (0,452- } \\
\text { 48,03 мкг/мл), МСF-7 (рак } \\
\text { молочної залози) (1,48-30,99 } \\
\text { мкг/мл) } \\
\text { Антималярійна: (1,03- } \\
\text { 5,31 мкг/мл) Plasmodium } \\
\text { falciparum K1 } \\
\text { Антивipyсна: Herpes simplex } \\
\text { virus type-1 (11,01 мкг/мл) }\end{array}$ & \begin{tabular}{|c|} 
\\
Медицина \\
Фармацев- \\
тична \\
промисловість
\end{tabular} & {$[40]$} \\
\hline $\begin{array}{l}\text { Penicillium } \\
\text { brasilianum } \\
\text { LAB } 34\end{array}$ & \begin{tabular}{|c} 
Меротерпеноїди: \\
дигідроаустін, \\
аустін \\
Спирт: D- \\
манітол \\
Кислота: \\
пеніцилова
\end{tabular} & \begin{tabular}{|c|} 
Антибактеріальна: \\
Staphylococcus aureus ATCC \\
29213 (512 мкг/мл), Listeria \\
monocytogenes ATCC 15313 \\
(256 мкг/мл), Bacillus cereus \\
АТСС 1177 (256 мкг/мл), \\
Salmonela typhimurium ATCC \\
14028 (512 мкг/мл), Esche- \\
richia coli АТСС 25922 (256 \\
мкг/мл), Citrobacter freundii \\
АТСС 8090 (256 мкг/мл)
\end{tabular} & $\begin{array}{c}\text { Медицина } \\
\text { Фармацев- } \\
\text { тична } \\
\text { промисловість }\end{array}$ & {$[41]$} \\
\hline \multicolumn{5}{|c|}{ Ендофітні } \\
\hline $\begin{array}{c}\text { Talaromyces sp. } \\
\text { cf-16 }\end{array}$ & $\begin{array}{c}\text { Алкалоїди: } \\
\text { роквефортін C, } \\
\text { Z-роквефортін C, } \\
\text { вірідікатол, } \\
\text { пенітрем А, } \\
\text { пеніянтін А, } \\
\text { паспалін, 3- } \\
\text { деоксо-4b- } \\
\text { деоксипаксілін }\end{array}$ & $\begin{array}{c}\text { Токсична: Artemia salina } \\
\text { (3,1-106,4 мкг/мл) } \\
\text { Антимікробна: Staphylococcus } \\
\text { aureus }(8,3-11,8 \text { мкг/мл) }\end{array}$ & $\begin{array}{c}\text { Медицина } \\
\text { Фармацев- } \\
\text { тична } \\
\text { промисловість }\end{array}$ & {$[42]$} \\
\hline $\begin{array}{c}\text { Talaromyces sp. } \\
\text { ZH-154 }\end{array}$ & $\begin{array}{l}\text { Стереоізомери } \\
\text { аустдіолу: 7- } \\
\text { епіуастдіол, 8-О- } \\
\text { метилепіаустдіол } \\
\text { Ксантони: } \\
\text { сецалонова } \\
\text { кислота А, } \\
\text { стемфіпериле- } \\
\text { нол, норліхек- } \\
\text { сантон } \\
\text { Антрахінони: } \\
\text { скірин, емодін }\end{array}$ & $\begin{array}{c}\text { Антибактеріальна: } \\
\text { Staphylococcus aureus (АТСС } \\
27154) \text { (12,5-50 мкг/мл), } \\
\text { Escherichia coli (АТСС 25922) } \\
\text { (6,25-25 мкг/мл), Sarcina } \\
\text { ventriculi (АТСС 29068) } \\
\text { (3,12-50 мкг/мл), Pseudo- } \\
\text { monas aeruginosa (АТСC } \\
\text { 25668) (6,25-25 мкг/мл) } \\
\text { Антифунгальна: Candida } \\
\text { albicans (АТСС 10231) (6,25- } \\
\text { 25 мкг/мл), Aspergillus niger } \\
\text { (АТСС 13496) (6,25-50 } \\
\text { мкг/мл), Fusarium охуsроrum f. } \\
\text { мр. сubense (12,5-50 мкг/мл) } \\
\text { Цитотоксична: карцинома } \\
\text { шкіри людини лінії КВ } \\
\text { (0,63-20,38 мкг/мл) }\end{array}$ & \begin{tabular}{|c} 
Медицина \\
Фармацев- \\
тична \\
промисловість \\
\end{tabular} & {$[43]$} \\
\hline
\end{tabular}




\begin{tabular}{|c|c|c|c|c|}
\hline \multicolumn{5}{|c|}{ Продовження табл. 4} \\
\hline 1 & 2 & 3 & 4 & 5 \\
\hline $\begin{array}{l}\text { T. flavus CCTCC } \\
\text { M } 2010266\end{array}$ & $\begin{array}{c}\text { Терпени: } \\
\text { таларопероксиди } \\
\text { A-D, } \\
\text { степероксид В }\end{array}$ & $\begin{array}{c}\text { Цитотоксична: клітини раку } \\
\text { людини лінії МСF-7 (1,33- } \\
19,77 \text { мкг/мл), MDA-MB-435 } \\
(0,91-11,78 \text { мкг/мл), HepG2 } \\
(0,90-15,11 \text { мкг/мл), HeLa } \\
(1,31-13,7 \text { мкг/мл), PC-3 } \\
(0,70-5,70 \text { мкг/мл) }\end{array}$ & Медицина & [31] \\
\hline $\begin{array}{c}\text { Aspergillus } \\
\text { fumigatus R7 }\end{array}$ & 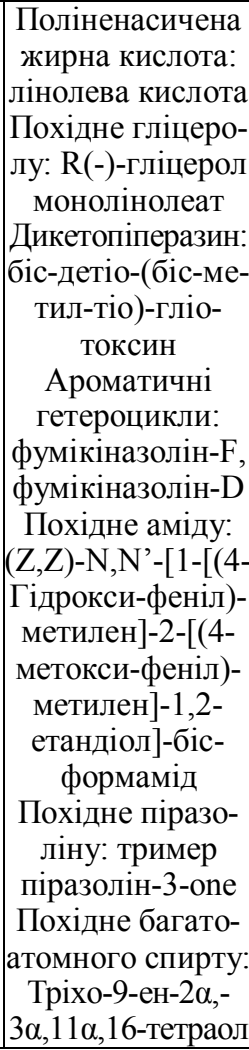 & \begin{tabular}{|c|} 
\\
\\
Антитуберкульозна: \\
Mycobacterium tuberculosis \\
(48,8 нг/мл) \\
Цитотоксична: (10 мкг/мл) \\
солоні креветки (85\%) \\
Антибактеріальна: (40 мкг/мл) \\
Bacillus subtilis (11-15 мм), \\
Staphylococcus aureus (11-13 \\
мм), Streptomyces \\
viridochromogenes (12-16 мм) \\
Антифунгальна: Candida \\
albicans (11-12 мм), Mucor \\
miehi (12-14 мм)
\end{tabular} & $\mid \begin{array}{c}\text { Медицина } \\
\text { Фармацев- } \\
\text { тична } \\
\text { промисловість }\end{array}$ & {$[34]$} \\
\hline \multicolumn{5}{|c|}{ Морського походження } \\
\hline $\begin{array}{l}\text { Talaromyces sp. } \\
\text { LF458 }\end{array}$ & $\begin{array}{c}\text { Оксафеналенові } \\
\text { димери: таларо- } \\
\text { міцесони А-B } \\
\text { Ізопентеніл ксан- } \\
\text { тенон: таларо- } \\
\text { ксантенон } \\
\text { Похідні дифені- } \\
\text { лового етеру: } \\
\text { 1',3',-1'-дегідрок- }^{\prime} \text { сипеніцилід, 1',2'- } \\
\text { дегідропеніцилід, } \\
\text { верміксоцин А- } \\
\text { В, 3'-метокси-1'2'- } \\
\text { дегідропеніцилід, } \\
\text { AS-186с }\end{array}$ & $\begin{array}{c}\text { Антибактеріальна: } \\
\text { Staphylococcus epidermidis } \\
\text { (1,34-17,36 мкг/мл), } \\
\text { метицилін-резистентний } \\
\text { Staphylococcus aureus }(1,71- \\
\text { 19,5 мкг/мл) } \\
\text { Цитотоксична: ракові клітини } \\
\text { ліній NIH } 3 \text { T3 (20,19-41,21 } \\
\text { мкг/мл), Нер G2 (25,41-38,95 } \\
\text { мкг/мл) }\end{array}$ & \begin{tabular}{|} 
Медицина \\
Фармацев- \\
тична \\
промисловість \\
\end{tabular} & [32] \\
\hline
\end{tabular}


Закінчення табл. 4

\begin{tabular}{|c|c|c|c|c|}
\hline 1 & 2 & 3 & 4 & 5 \\
\hline $\begin{array}{c}\text { Talaromyces sp. } \\
\text { HQ596522 }\end{array}$ & $\begin{array}{c}\text { Похідні } \\
\text { дифенілового } \\
\text { етеру: } \\
\text { талароміцини А- } \\
\text { С, метиловий } \\
\text { естер тенелінової } \\
\text { кислоти А, } \\
\text { пурпактін С, } \\
\text { пурпактін С', } \\
\Delta 1 \text { ',3',-1'- } \\
\text { дегідроксипеніци } \\
\text { лід, пеніцилід, } \\
\text { пурпактін А }\end{array}$ & $\begin{array}{c}\text { Цитотокчисна: гепатоми } \\
\text { НерG2 (4,3 мкг/мл) та Нер3В } \\
\text { (9,0 мкг/мл), рак молочної } \\
\text { залози MCF-7/ADR }(8,2-16,4 \\
\text { мкг/мл), рак передміхурової } \\
\text { залози РС-3 (7,8-15,8 } \\
\text { мкг/мл), рак товстої кишки } \\
\text { НСТ-116 (9,8-15,1 мкг/мл) } \\
\text { Антизапальна: Balanus } \\
\text { amphitrite (2,2-4,8 мкг/мл) }\end{array}$ & \begin{tabular}{|c|} 
Медицина \\
Фармацев- \\
тична \\
промисловість
\end{tabular} & [33] \\
\hline Aspergillus sp. & \begin{tabular}{|c} 
Алкалоїд: 3-((1- \\
гідрокси-3-(2- \\
метилбут-3-ен-2- \\
ил)-2- \\
оксоіндолін- 3- \\
ил)метил)-1- \\
метил-3,4- \\
дигідробензо \\
[е][1,4]діазепін- \\
2,5-діон \\
Терпеноїд: \\
аусталід R \\
Похідне \\
гідроксицінамічн \\
ої кислоти: 8-O- \\
$4-$ \\
дегідродиферуло \\
ва кислота \\
Цитохалазін: \\
цитохалазін Z17 \\
Лактам: \\
дигідроізофлавіп \\
уцин
\end{tabular} & $\begin{array}{c}\text { Антибактеріальна: } \\
\text { Staphylococcus aureus }(0,001 \\
\text { мкг/мл), Halomonas } \\
\text { aquamarina }(0,001-0,1 \\
\text { мкг/мл), Polaribacter irgensii } \\
\text { (0,01-0,1 мкг/мл), } \\
\text { Pseudoalteromonas elyakovii } \\
\text { (0,001-0,1 мкг/мл), } \\
\text { Roseobacter litoralis }(0,0001- \\
\text { 0,01 мкг/мл), Shewanella } \\
\text { putrefaciens }(0,001-0,1 \\
\text { мкг/мл), Vibrio harveyi } \\
\text { (0,001-0,1 мкг/мл), V. } \\
\text { natriegens }(0,001-10 \text { мкг/мл), } \\
\text { V. proteolyticus }(0,1 \text { мкг/мл), V. } \\
\text { carchariae }(0,01-1 \text { мкг/мл) }\end{array}$ & \begin{tabular}{|c} 
Медицина \\
Фармацев- \\
тична \\
промисловість
\end{tabular} & [36] \\
\hline $\begin{array}{c}\text { Penicillium } \\
\text { brocae MA-231 }\end{array}$ & $\begin{array}{c}\text { Похідні } \\
\text { дикетопіперазин } \\
\text { у: } \\
\text { пеніціброцазини } \\
\text { А-E, конгенер }\end{array}$ & $\begin{array}{c}\text { Антибактеріальна: } \\
\text { Staphylococcus aureus (0,25- } \\
32 \text { мкг/мл), Micrococcus luteus } \\
\text { (0,25 мкг/мл), (патогени } \\
\text { рослин) Gaeumannomyces } \\
\text { graminis } 0,25-64 \text { мкг/мл) }\end{array}$ & \begin{tabular}{|c|} 
Медицина \\
Фармацев- \\
тична \\
промисловість \\
Сільськогоспо \\
дарська \\
промисловість \\
\end{tabular} & [38] \\
\hline $\begin{array}{c}\text { Penicillium } \\
\text { commune QSD-17 }\end{array}$ & $\begin{array}{c}\text { Похідні } \\
\text { азафілону: } \\
\text { комазафілони А- } \\
\text { F }\end{array}$ & \begin{tabular}{|c|} 
Антибактеріальна: метицилін- \\
резистентний Staphylococcus \\
aureus (16-128 мкг/мл), \\
Pseudomonas fluorescens (16- \\
128 мкг/мл), Bacillus subtilis \\
(16-256 мкг/мл) \\
Цитотоксична: \\
аденокарцинома підшлункової \\
залози SW1990 (26-53 мкM)
\end{tabular} & \begin{tabular}{|c|} 
\\
Медицина \\
Фармацев- \\
тична \\
промисловість \\
\end{tabular} & {$[37]$} \\
\hline
\end{tabular}


Велика кількість грибів роду Talaromyces синтезують різноманітні алкалоїди та естери [29-33]. Наприклад, штам Talaromyces thermophilus YM1-3 утворює алкалоїди талатермофілінс А та В, яким за концентрації $0,5-1,0$ мкг/мл притаманна нематоцидна активність щодо Panagrellus redivivus [29].

Штам T. pinophilus AF-02 продукує естери талароміколіди А-С, які за концентрацій 6,25-25 мкг/мл інгібують ріст Clostridium perfringens (A і C) та Bacillus megaterium (B) [30]. Крім естерів, цей мікроорганізм синтезує жирну кислоту 2-гідроксирадіклонову кислоту, яка у концентрації 12,5 мкг/мл пригнічуе ріст Escherichia coli.

Представники роду Talaromyces утворюють також і терпени. Так, T. flavus CCTCC M 2010266 синтезує таларопероксиди A-D, степероксид B, що проявляють цитотоксичний ефект на клітини раку людини лінії MCF-7 $(1,33$ 19,77 мкг/мл), MDA-MB-435 (0,91-11,78 мкг/мл), HepG2 (0,90-15,11 мкг/мл), HeLa (1,31-13,7 мкг/мл), PC-3 (0,70-5,70 мкг/мл) [31]. Цитотоксичною дією щодо ракових клітин ліній NIH 3 T3, Hep G2 [32] та гепатоми HepG2, Нер3B, раку молочної залози MCF-7/ADR, раку передміхурової залози PC-3, раку товстої кишки НСТ-116 [33] характеризуються і похідні дифенілового етеру, синтезовані Talaromyces sp. LF458 та Talaromyces sp. HQ596522.

Відомими продуцентами вторинних метаболітів $\epsilon$ також гриби роду Aspergillus і Penicillium. Так, ендофіт Aspergillus fumigatus R7 утворює фумікіназолін-F та фумікіназолін-D, які за концентрації 40 мкг/мл інгібують ріст Bacillus subtilis (зона затримки росту 12 та 15 мм відповідно), Staphylococcus aureus (12 та 15 мм), Candida albicans (11 та 11 мм) та Mucor miehi (12 та 13 мм) [34]. Окрім ендофітних штамів, до синтезу практично цінних вторинних метаболітів здатні і морські гриби. Так, Aspergillus flavipes LF584 та Aspergillus sp. продукують цитохалазани - інгібітори ферментів, що діють на проліферацію ракових клітин: недрібноклітинний рак легенів NCI-H460 (3,4-55,2 мкг/мл), MCF-7 (5,0-33,4 мкг/мл), гліома центральної нервової системи SF-268 (3,952,6 мкг/мл) [35] та інгібують ферменти синтезу білка, проявляючи тим самим антибактеріальний ефект щодо широкого спектру мікроорганізмів у досить низькій $(0,001-0,1$ мкг/мл) концентрації [36].

Штам Penicillium commune QSD-17, виділений із зразків Південного Китайського моря, синтезує похідні азафінолу — комазафіноли $\mathrm{A}-\mathrm{F}$, з яких камафізоли С-E проявляють антибактеріальну активність щодо метицилін-резистентного Staphylococcus aureus (16-128 мкг/мл), Pseudomonas fluorescens (16128 мкг/мл) та Bacillus subtilis (16-256 мкг/мл), а комазафілони D-F — цитотоксичну дію на аденокарценоми підшлункової залози SW1990 [37]. Інший морський штам Penicillium brocae MA-231 продукує похідні дикетопіперазину: пеніціброцазини А-E, конгенер, що проявляють антибактеріальну дію на Staphylococcus aureus (0,25-32 мкг/мл), Micrococcus luteus (0,25 мкг/мл), та антифунгальну — на Gaeumannomyces graminis (0,25—64 мкг/мл) [38].

\section{Висновки}

Отже, вторинні метаболіти, синтезовані бактеріями родин Bacillaceae та Paenibacillaceae, актинобактеріями родин Streptomycetaceae та Micromonosporaceae, а також грибами родини Trichocomaceae у вигляді комплексу 
подібних сполук та речовин, що належать до різних класів, завдяки широкому спектру біологічної активності можуть стати альтернативою відомим антимікробним сполукам у медицині, ветеринарії та сільському господарстві.

\section{Лiтература}

1. Безбородов А.М., Квеситадзе Г.И. Микробиологический синтез. Санкт-Петербург: проспект Науки. 2011. 144 с.

2. Bowler P.G. Antibiotic resistance and biofilm tolerance: a combined threat in the treatment of chronic infections. J. Wound Care. 2018. Vol. 27, No. 5. P. 273-277. doi: 10.12968/jowc.2018.27.5.273.

3. Purves K., Macintyre L., Brennan D., Hreggviðsson G.Ó., Kuttner E., Ásgeirsdóttir M.E., Young L.C., Green D.H., Edrada-Ebel R., Duncan K.R. Using molecular networking for microbial secondary metabolite bioprospecting. Metabolites. 2016. Vol. 6, No. 1. doi: 10.3390/metabo6010002.

4. Kundranda M.N., Niu J. Albumin-bound paclitaxel in solid tumors: clinical development and future directions. Drug Des Devel Ther. 2015. Vol. 24, No. 9. P. 3767-3777. doi: 10.2147/DDDT.S88023.

5. Martínez-Castro M., Barreiro C., Romero F., Fernández-Chimeno R.I., Martín J.F. Streptomyces tacrolimicus sp. nov., a low producer of the immunosuppressant tacrolimus(FK506). Int J. Syst Evol Microbiol. 2011. Vol. 61, No. 5. P. 1084 -1088. doi: 10.1099/ijs.0.024273-0.

6. Boruta T., Bizukojc M. Production of lovastatin and itaconic acid by Aspergillus terreus: a comparative perspective. World J. Microbiol Biotechnol. 2017. Vol. 33, No. 2. doi: 10.1007/s11274-017-2206-9.

7. Liang T.-W., Wu C.-C., Cheng W.-T. et. al. Exopolysaccharides and antimicrobial biosurfactants produced by Paenibacillus macerans TKU029. Appl. Biochem. Biotechnol. 2014. Vol. 172, No. 2. P. 933 950. doi:10.1007/s12010-013-0568-5

8. Arrebola E., Jacobs R. and Korsten L. Iturin A is the principal inhibitor in the biocontrol activity of Bacillus amyloliquefaciens PPCB004 against postharvest fungal pathogens. J. Appl. Microbiol. 2010. Vol. 108, No. 2. P. 386-395.

9. Kumar S.N., Mohandas C., Siji J.V. et. al. Identification of antimicrobial compound, diketopiperazines, from a Bacillus sp. $\mathrm{N}$ strain associated with a rhabditid entomopathogenic nematode against major plant pathogenic fungi. J. Appl. Microbiol. 2012. Vol. 113, No. 4. P. 914-924. doi: 10.1111/j.1365-2672.2012.05385.x.

10. Liu B., Huang L., Buchenauer H. et. al. Isolation and partial characterization of an antifungal protein from the endophytic Bacillus subtilis strain EDR4. Pestic. Biochem. Phys. 2010. Vol. 98, No. 2. P. 305-311.

11. Fuchs S.W., T.W., Bochmann S. et. al. Entianin, a novel subtilin-like lantibiotic from Bacillus subtilis subsp. spizizenii DSM 15029T with high antimicrobial activity. Appl. Environ. Microbiol. 2011. Vol. 77, No. 5. P. 1698-1707. doi: 10.1128/AEM.01962-10.

12.Habbu P., Warad V., Shastri R. et. al. Antimicrobial metabolites from marine microorganisms. Chin. J. Nat. Med. 2016. Vol. 14, No. 2. P. 101-116.

13.Poli A., Anzelmo G., Nicolaus B. et. al. Bacterial exopolysaccharides from extreme marine habitats: production, characterization and biological activities. Mar. Drugs. 2010. Vol. 8, No. 6. P. 1779-1802. doi: 10.3390/md8061779.

14. Liu J., Luo J., Ye H. et. al. Preparation, antioxidant and antitumor activities in vitro of different derivatives of levan from endophytic bacterium Paenibacillus polymyxa EJS-3. Food. Chem. Toxicol. 2012. Vol. 50, No. 3-4. P. 767-772. doi: 10.1016/j.fct.2011.11.016.

15. Devi P., Wahidullah S., Rodrigues C. et. al. The sponge-associated bacterium Bacillus licheniformis SAB1: a source of antimicrobial compounds. Mar. Drugs. 2010. Vol. 8, No. 4. P. 1203-1212. doi: 10.3390/md8041203. 
16. Hwang K.-S., Kim H. U., Charusanti P. et. al. Systems biology and biotechnology of Streptomyces species for the production of secondary metabolites. Biotechnol. Adv. 2014. Vol. 32, No. 2. P. 255-268. doi: 10.1016/j.biotechadv.2013.10.008.

17. Khebizi N., Boudjella H., Bijani C. et. al. Oligomycins A and E, major bioactive secondary metabolites produced by Streptomyces sp. strain HG29 isolated from a Saharan soil. J. Mycol. Med. 2018. Vol. 28, No. 1. doi: 10.1016/j.mycmed.2017.10.007.

18. Cihák M., Kameník Z., Šmídová K. et. al. Secondary metabolism of germinating Streptomycete spores. Front. Microbiol. 2017. Vol. 8. P. 1-13. doi: 10.3389/fmicb.2017.02495.

19. Djinni I., Defant A., Kecha M. et. al. Antibacterial polyketides from the marine algaderived endophitic Streptomyces sundarbansensis: a study on hydroxypyrone tautomerism. Mar. Drugs. 2013. Vol. 11, No. 1. P. 124-135. doi: 10.3390/md11010124.

20. Supong K., Thawai C., Suwanborirux K. et. al. Antimalarial and antitubercular Cglycosylated benz $[\alpha]$ anthraquinones from the marine-derived Streptomyces sp. BCC45596. Phytochem. Lett. 2012. Vol. 5, No. 3. P. 651-656. https:.doi.org/10.1016/j.phytol.2012.06.015.

21. Zhang W., Liu Z., Li S. et. al. Fluostatins I-K from the south china sea-derived Micromonospora rosaria SCSIO N160. J. Nat. Prod. 2012. Vol. 75, No. 11. P. 1937-1943. doi: $10.1021 / \mathrm{np} 300505 \mathrm{y}$.

22. Alshaibani M. M., Zin N. M., Jalil J. et. al. Isolation, purification, and characterization of five active diketopiperazine derivatives from endophytic Streptomyces SUK 25 with antimicrobial and cytotoxic activities. J. Microbiol. Biotechnol. 2017. Vol. 27, No. 11. P. 12491256. doi: 10.4014/jmb.2017.2711.2074.

23. Sun P., Maloney K. N., Nam S.-J. et. al. Fijimycins A C, three antibacterial etamycinclass depsipeptides from a marine-derived Streptomyces sp.. Bioorg. Med. Chem. 2011. Vol. 19, No. 22. P. 6557-6562. doi: 10.1016/j.bmc.2011.06.053.

24. Zhou H., Yang Y., Peng T. et. al. Metabolites of Streptomyces sp., an endophytic actinomycete from Alpinia oxyphylla. Nat. Prod. Res. 2014. Vol. 28, No. 4. P. 265-267.

25. Zhang J., Wang J.-D., Liu C.-X. et. al. A new prenylated indole derivative from endophytic actinobacteria Streptomyces sp. neau-D50. Nat. Prod. Res. 2014. Vol. 28, No. 4. P. 431-437. doi: 10.1080/14786419.2013.830219

26. Yang X., Peng T., Yang Y. et. al. Antimicrobial and antioxidant activities of a new benzamide from endophytic Streptomyces sp. YIM 67086. Nat. Prod. Res. 2015. Vol. 29, N 4. P. 331-335. doi: 10.1080/14786419.2014.945174.

27. Wang P., Kong F., Wei J. et. al. Alkaloids from the mangrove-derived actinomycete Jishengella endophytica 161111. Mar. Drugs. 2014. Vol. 12, n 1 P. 477-490. doi: 10.3390/md12010477.

28.Boruta T.. Uncovering the repertoire of fungal secondary metabolites: from Fleming's lab to the International Space Station. Bioengineered. 2018. V. 9, No. 1. P. 12-16. doi: 10.1080/21655979.2017.1341022.

29. Zhai M.-M., Li J., Jiang C.-X. et. al. The bioactive secondary metabolites from Talaromyces species. Nat. Prod. Bioprospect. 2016. Vol. 6, No. 1. P. 1-24. doi: 10.1007/s13659-0150081-3.

30. Zhai M.M., Niu H.T., Li J. et. al. Talaromycolides A C, novel phenyl-substituted phthalides isolated from the green chinese onion-derived fungus Talaromyces pinophilus AF-02. J. Agric. Food Chem. 2015. Vol. 63, No. 43. P. 9558 - 9564. doi: 10.1021/acs.jafc.5b04296.

31. Nicoletti R., Salvatore M. M., Andolfi A. Secondary metabolites of mangrove-associated strains of Talaromyces. Mar. Drugs. 2018. Vol. 16, No. 12. doi:10.3390/md16010012.

32. Wu B., Ohlendorf B., Oesker V. et. al. Acetylcholinesterase inhibitors from a marine fungus Talaromyces sp. strain LF458. Mar. Biotechnol. (NY). 2015. Vol. 17, No. 1. P. 110 119. doi: 10.1007/s10126-014-9599-3.

33. Chena M., Hana L., Shao C.-L. et. al. Bioactive diphenyl ether derivatives from a gorgonian-derived fungus Talaromyces sp.. Chem. Biodivers. 2015. Vol. 12, No. 3. P. $443-$ 450. doi: 10.1002/cbdv.201400267. 
34. Shaaban M., Nasr H., Hassan A. Z. et. al. Bioactive secondary metabolites from endophytic Aspergillus fumigatus: structural elucidation and bioactivity studies. Rev. Latinoamer. Quim. 2013. Vol. 41, No. 1. P. 50-60.

35. Wiese J., Ohlendorf B., Blümel M. et. al. Phylogenetic identification of fungi isolated from the marine sponge Tethya aurantium and identification of their secondary metabolites. Mar. Drugs. 2011. Vol. 9, No. 4. P. 561-585. doi: 10.3390/md9040561.

36. Zhoua Y., Debbaba A., Wray V. et. al. Marine bacterial inhibitors from the spongederived fungus Aspergillus sp.. Tetrahedron. Lett. 2014. Vol. 55, No. 17. P. 2789-2792.

37. Gao S.-S., Li X.-M., Zhang Y. et. al. Comazaphilones A-F, azaphilone derivatives from the marine sediment-derived fungus Penicillium commune QSD-17. J. Nat. Prod. 2011. Vol. 74, No. 2. P. 256-261. doi: 10.1021/np100788h.

38. Meng L.-H., Zhang P., Li X.-M. et. al. Penicibrocazines A E, five new sulfide diketopiperazines from the marine-derived endophytic fungus Penicillium brocae. Mar. Drugs. 2015. Vol. 13, No. 1. P. 276-287. doi: 10.3390/md13010276.

39. Nagia M. M., El-Metwally M. M., Shaaban M. et. al. Four butyrolactones and diverse bioactive secondary metabolites from terrestrial Aspergillus flavipes MM2: isolation and structure determination. Bioorg. Med. Chem. Lett. 2012. Vol. 2, No. 1. doi: 10.1186/2191-2858-2-9.

40. Yodsing N., Lekphrom R., Sangsopha W. et. al. Secondary metabolites and their biological activity from Aspergillus aculeatus KKU-CT2. Curr. Microbiol. 2017. Vol. 75, No. 5. doi: 10.1007/s00284-017-1411-y.

41. Bazioli J. M., Amaral L. D. S., Fill T. P. et. al. Insights into Penicillium brasilianum secondary metabolism and its biotechnological potential. Molecules. 2017. Vol. 22, No. 6. doi:10.3390/molecules22060858.

42. Haibin Y., Fang L., Naiyun J. Alkaloids from an algicolous strain of Talaromyces sp.. Chin. J. Oceanol. Limn. 2015. Vol. 34, No. 2. doi: 10.1007/s00343-015-4316-2.

43.Liu F., Cai X.-L., Yang H. et. al. The bioactive metabolites of the mangrove endophytic fungus Talaromyces sp. ZH-154 isolated from Kandelia candel (L.) Druce. Planta. Med. 2010. Vol. 76, No. 2. P. 185-189. doi: 10.1055/s-0029-1186047. 